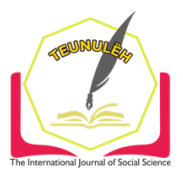

Jurnal Ilmiah Teunuleh

The International Journal of Social Sciences

Vol. 1, Issue. 2, Dec 2020

E-ISSN: 2746-4393

\title{
STRENGTHENING THE CONCEPT OF GENDER FROM RESEARCH ON SEXUAL DIVISION OF FISHERMEN COMMUNITY (For Development of PIPS Study Program)
}

\author{
Nuriza Dora ${ }^{1}$ \\ Rora Rizky Wandini ${ }^{2}$ \\ Lailatun Nur Kamalia ${ }^{3}$ \\ ${ }^{123}$ Fakultas IImu Tarbiyah dan Keguruan, UIN Sumatera Utara \\ 11nuriza889@gmail.com
}

\begin{abstract}
This paper seeks to describe how women or fishermen's wives in Percut Village decided to do work as shellfish seekers as a strategy in meeting household financial needs. The method used is descriptive qualitative research to explain how financial problems faced by women in Percut Village and how they deal with their life problems. Data collection techniques are carried out by observance, observation of participation and interviews. The results showed that with the decline in fishermen's incomes caused emotional and psychological pressures for fishermen's wives to meet household needs so that they sought alternative jobs as shellfish seekers without neglecting the position of women with the main task of taking care of the household. There are some obstacles and challenges faced especially in childcare but they have to find strategies to overcome them.
\end{abstract}

Keywords: Women, Division of Work, Fishermen's Wife

\section{A. Introduction}

Sea expansion according to calculations from the Directorate General of Marine, marine biota resource reserves are many such as fish, shrimp, mollusks, crabs that can be exploited with an average amount of 6 million tons per year without jeopardizing the continuity of marine resources laninnya (Comitini and Hardjolukito, 1983:38 Bailey, 1988 in Semedi, 2003). Fishing is very necessary as a foreign exchange enhancer for the Indonesian economy. Because, this is a source of income for half a million fishermen and many more businesses involved in fishing such as trade, fish processing, and transportation (Semedi, 2003). 
Attention to coastal areas on the basis that, this area holds considerable potential for natural resources. In addition, there is also the social potential of the community that will manage these resources in a sustainable manner. The potential of this community is very important because most of the population who live on the coast is relying on the management of marine resources and fisheries. However, in general, people who live around the beach are classified as underprivileged communities.

Women's involvement in making a living is a forced situation, it is caused by low husband income or irregular husband income so that women have to come to work to increase income, both as income enhancers and as the main breadwinner. Therefore, the burden of women's duties is getting heavier, on the one hand women have to do housework, on the other hand she also has to work at home.

This is as Ware said (in Suratiyah, et al., 1994) there are two main reasons why women work. The first reason is that women "have to" work because the economic condition of the family is low so it needs women's participation and the second reason is to "choose" to work in a family whose economy is strong so that it requires less female participation in family life. Furthermore, suratiyah (1994) and Hardyastuti (1991) in the results of their research, often the living produced by women become a mainstay in meeting the needs of the family.

Most of the women in the Percut region work at sea. Most of them are housewives, teenagers and elderly women. Being a clam seeker is the main job for women. It is based on regular income earned after returning from the sea. Finding shellfish makes it easy for women to make money and gives women freedom in managing family finances.

Women's work in the field of economics is a phenomenon that is common among the community. Many studies have proven that women allocate their time is not limited to the domestic sector such as taking care of the household. Nowadays, women's activities have also penetrated into the public sector. Similar research has also been proven by Andriyati (1996) in his writing entitled women and the economy of fishermen in Kenjeran Village and Sukolilo Village. According to him, one of the adaptive strategies of coastal fishing households is the division of labor between the boat owner and his wife or the fishermen and his wife. This division of labor is a mutual agreement between them, husband and wife processing and selling fish and doing household chores. Based on this strategy, it will appear how the role of husband or fisherman or the role of beach 
Strengthening the Concept of Gender From Reasearch on Sexual Division of...

fisherman's wife based on their respective position or position as husband and wife in their home life.

Munawaroh's research (2007) on the role of fishing women in supporting family life shows that women as one of the family members, as well as other family members have the task and function of supporting the family. Since long time ago until now there are still members of the community who consider the duty of women in the family is to give birth to offspring, parenting, serving husbands, and taking care of the household. In later developments it turns out that the role of women in family life and society is growing.

\section{B. Research Method}

This research uses qualitative research that seeks to uncover problems related to research. Qualitative research is used due to several considerations. Qualitative is easier to use when dealing with double reality, this method also presents directly the nature of the relationship between researchers and informants and this method is more sensitive and more able to adjust to many sharpening of mutual influence and to the patterns of values faced. The use of this approach is more effective because at the time of the interview there is a direct argument between the researcher and the informant. This allows researchers to get more information from informants.

The research method is descriptive by focusing the study on the strategies of women fishermen in the household economy. Data collection techniques use observation or observation methods, interviews and participation observations. Observations are carried out to determine the situation in the context of space and time in the research area. This is because the data obtained from the interview alone is not enough to explain the phenomenon that occurred. Therefore, activities are needed by going directly to the research site while conducting observations. The observation used is participation observation, where researchers are not only limited to making observations but also living with the community where this research was conducted. The interview technique is done to several informants, namely key informants and ordinary informants. The key informants are the people who master the problem because he has been integrated with his work for a long time and is still fully involved in it. Ordinary informants understand a little about the problems even if they are not working in that field. 


\section{Results and Discussion}

Geographically, Percut Sei Tuan sub-district is located in Deli Serdang Regency and the administrative boundaries of Percut Sei Tuan SubDistrict are bordered by several subdistricts in Medan and also bordered by Labuhan Deli and Batang Kuis subdistricts. The administrative boundaries of Percut Sei Tuan sub-district are as follows:

- The North is bordered by the Malacca Strait.

- South side is bordered by the city of Medan.

- East side is bordered by Batang Kuis Sub-District and Labu Beach District.

- The west is bordered by the city of Medan and District Labuhan Deli.

The area of Percut Sei Tuan SubDistrict is $190.79 \mathrm{Km}^{2}$ consisting of 18 villages, 2 villages, 230 hamlets, and 24 neighborhoods with the capital of the sub-district is Tembung Village. The village that has the largest administrative area is Saentis Village has an area of $24.00 \mathrm{Km}^{2}$, while the area with the smallest area is Kelurahan Kenangan Baru which has an area of $0.72 \mathrm{Km}^{2}$.

\section{History of Economic, Political and Socio-Cultural Life of Percut Village Community}

Around 1976, the village began to be visited by migrants from various regions. The large number of people arriving is due to the rich potential of marine resources available in the area. According to Pak Makmun (70 years old) formerly the fishing community only used rowing boats that can be found around tangkahan. Over the past few years, many have used engine boats. Fishing equipment used in the past is nets but since the use of machine boats, fishermen use tuamang trawlers more. Tuamang trawler is a fishing tool that can attract a large number of fish both large and small fish can be lifted by tuamang trawlers. This problem began to cause public unrest in 1980 due to the dominance of engine boats and tuamang trawlers. Fishermen who use nets get very little fish because the fish has been fished by tuamang trawlers.

Around 1982 the construction had started to enter Percut Village. Through the village equipment entrepreneurs ask permission to develop the economic life of the community by utilizing the potential in the area for the prosperity of the community.the main target of these entrepreneurs is the clearing of land in fish cultivation. This land is in the form of ponds, namely shrimp ponds and freshwater fish. The disadvantage lies in the logging of mangroves that thrive in coastal areas. Mangrove forest has the ability to penetrate in holding sea water so as not to reach land. Mangrove forest is also a gathering place for shrimp and crabs that can be taken at any time by the community. With the decrease of mangrove forests cause frequent flooding around community [254] 
settlements. The situation mentioned above makes the life of the fishing community less prosperous. So that caused the wife of fishermen to do work in the public sector.

\section{Why Women In The Village Are Looking for Shellfish}

The increasingly urgent need and lack of income made the people of Percut Village take other alternatives to make additional money. Money is needed for food and drinking purposes, children's education, housing and other primary, secondary and tertier needs. The decline in husband's income makes women have to be good at managing expenses. Strategies must be carried out so that low incomes can be maximized for the needs of life.

Emotional pressures are often faced by women in Percut Village when they want to spend money on living necessities derived from their husbands who work as fishermen. This makes the wives participate in going down to the sea with their husbands, whether it is looking for shellfish or looking for fish by private boat. This is done so that the family's income can increase to meet the growing needs of life.

At first, the woman who went down to sea got booed from the local community. According to them, a woman can manage a household and rely on her husband's income from going to sea. Over time, with the regular income from work at sea, women around this village also participated in working in search of shellfish.

As stated by Ningsih (18 years old) a resident of Bagan Percut, he will go down to the sea looking for shellfish if there is an urgent need such as to buy his personal needs that have run out or even to help his family members. He likes to find shellfish because after returning from the sea he can already earn money and spend the income according to his interests.

As with fishing, the time spent picking up shellfish is also highly determined by the tides. When the tide is marked by high sea water, women cannot go to sea. Not only women, this season men also can not go down to sea because it can put their lives at risk. In one month as much as possible only 2 weeks of time can be used to go to sea. Because depending on the height of the sea water hours to go to the sea can not be ascertained.

As for Percut itself usually this woman goes at 6 am, 2 pm on full moon, at 4 pm and $12 \mathrm{pm}$ in the dark moon. The time spent heading to and from the sea is about 6 hours. Leaving at 6 am from tangkahan usually this fisherman will come home around 12 pm. When the time goes out to sea at $2 \mathrm{pm}$ then, this fisherman arrives at the house and $8 \mathrm{pm}$. It's saddest to leave at 12 o'clock at night and come home at 6 a.m. The night sea 
becomes a story for the women of this area. Where when people are still engrossed in their blankets enjoying the silence of the night, women fishermen have to sacrifice their sleep in search of shells in order to get a few pieces of rupiah.

\section{Barriers and Challenges faced by Women}

In making a living there are many obstacles encountered both work-related and family-related. As a worker as well as concurrently as a housewife. Basically, it is the circumstances that force women to go to sea for a living. The husband's low income, the amount of education for children, the prices of family needs are getting higher, to the demands of emotions in themselves make women moved to ease the burden of husbands and please children by meeting their needs.

One of the perceived obstacles is rather annoying in determining sleep time. Erratic sea hours make it difficult for women to manage their sleep time. In one day, if the job of looking for fish and shellfish takes about 6-8 hours then, the time used to rejuvenate homework, rest and sleep is about 16 hours.

Women's involvement in this marine activity brings different perceptions to other communities. Another view says that, women who work in the sea looking for fish or shellfish are not a problem, as long as the work is still within reasonable limits. Another obstacle is the difficulty of arranging time to attend a funeral of relatives or friends whose homes are far away. Such events such as wedding parties, down bathing ceremonies, circumcision and others.

Seasickness is one of the obstacles experienced by fishermen's wives. Seasickness is not caused by health problems, they think the seasickness disease they experience is a congenital disease. Another obstacle is the weather conditions when they are at sea, often they are washed away by heavy rains accompanied by lightning. For four hours the women picked up shells, and they tried to survive the cold air and the frightening flash of lightning.

\section{Conclusion}

Fishermen's income has the same issue throughout Indonesia, namely the decrease from year to year. Of course, this has an impact on the fulfillment of insufficient household needs both for primary, secondary and tertier needs. The influence of psychology on women fishermen's wives in Percut Village when managing household finances encourages them to work in order to allocate money both for drinking needs, children's educational needs and other needs. One of the alternative jobs chosen is to go 
Strengthening the Concept of Gender From Reasearch on Sexual Division of...

down to the sea in search of shellfish. In addition to working outside the home women must also prioritize housework such as parenting, preparing food, and cleaning the house and its yard. The women of Percut village try to do these two types of work despite the obstacles or challenges they face.

\section{Bibliography}

Abdullah, I. (1990). Wanita Ke Pasar: Studi Tentang Perubahan Sosial Ekonomi Pedesaan. Populasi, 1(1).

Abdullah, I. (1995). Reproduksi Ketimpangan Gender : Partisipasi Wanita Dalam Kegiatan Ekonomi. Prisma, 6, 3-14.

Abdullah, I. (1997). Sangkan Paran Gender. Yogyakarta: Pustaka Pelajar.

Andriati, R. (1996). Wanita dari Subordinasi dan Marginalisasi Menuju Ke Pemberdayaan. Surabaya: AW Press.

Fakih, M. (1996). Analisis Gender dan Transformasi Sosial. Yogyakarta: Pustaka Pelajar.

Friedl, E. (n.d.). Society and Sex Roles", in James P. Spradly dan David W. McCurdy (ed) Conformity and Conflict, Reading in Cultural Antropology. Boston: Little, Brown and Company.

Kusnadi. (2002). Konflik Sosial Nelayan: Kemiskinan dan Perebutan Sumber Daya Perikanan. Yogyakarta: Lkis.

Kusnadi, \& et al. (2006). Perempuan Pesisir. Yogyakarta: LkiS.

Kusnadi, \& et al. (2007). Jaminan Sosial Nelayan. . Yogyakarta: LkiS.

Kusnadi, \& et al. (2007). Strategi Hidup Masyarakat Nelayan. Yogyakarta: LkiS.

Moleong, L. (2010). Metodologi Penelitian Kualitatif. Bandung: Remaja Rosdakarya.

Nirwati. (2018). Kontribusi Perempuan Pesisir Terhadap Peningkatan Pendapatan Rumah Tangga Nelayan. Makassar: Fakultas IImu Kelautan dan Perikanan UNHAS.

Purwadi, R. (2005). Peranan Istri Dalam Pemenuhan Kebutuhan Rumah Tangga Nelayan di Kalimantan Barat. Populasi, 16(2).

Rohmah, N. L. (2017). Pemberdayaan Perempuan Pesisir Dalam Pengelolaan Ikan Laut Untuk Meningkatkan Ekonomi Keluarga. Fakultas Ekonomi dan Bisnis Islam IAIN Purwokerto.

Semedi, P. (2003). Close To The Stone, Far From The Throne. Yogyakarta: Benang Merah.

Soerjono, S. (1982). Sosiologi Suatu Pengantar. Jakarta: Rajawali Press. 
Nuriza Dora, Rora Rizky Andini, Lailatun Nur Kamalia

Suratiyah, K., \& et al. (1991). Pembangunan Pertanian dan Peranan Wanita di Pedesaan Yogyakarta dan Bali. Yogyakarta: Pusat Penelitian Kependudukan Universitas Gadjah Mada.

Suratiyah, K., \& Hardyastuti., S. (1990). Profil Pekerja Wanita:, Kasus Proyek Bangunan Sekitar Kampus UGM. Populasi, 1(1). 